Original research article

\title{
Opportunities to increase compliance when administering first aid to children
}

\author{
Luca Anna Ferkai ${ }^{1 *}$, Bence Schiszler ${ }^{2}$, Bálint Bánfai ${ }^{2}$, Attila Pandúr ${ }^{2}$, József Betlehem ${ }^{2}$, \\ Krisztina Deutsch ${ }^{2}$ \\ ${ }^{1}$ University of Pécs, Doctoral School of Health Sciences, Pécs, Hungary \\ ${ }^{2}$ University of Pécs, Faculty of Health Sciences, Institute of Emergency Care and Health Pedagogy, Pécs, Hungary
}

\section{Abstract}

Background: The effectiveness of emergency children care and first aid is influenced by several external and internal factors, which often do not receive sufficient attention during treatment. The aim of our research was to assess the factors that influences children's cooperation in real situations.

Methods: Our target group consisted of 80 children ( $<16$ years) who required first aid at Lake Balaton during the summer vacation in 2016. The effect of music, child-friendly equipment and rewards on compliance were observed in contrast to ordinary care. For data collection observation, documentation, Wong-Baker and PSS (Pain Severity Score ) scales were used. For statistical analysis descriptive statistics, $\chi^{2}$-test and Cramer coefficient were applied.

Results: The research justified that music did not result in any positive changes in behaviour and did not decrease fear or pain, and that the documentation became more difficult. However, colourful tools and rewards led to significant improvements in the children's mood $(p<0.001)$, pain $(p=0.001)$, and behaviour $(p=0.07)$.

Conclusions: In first aid and professional medical training more emphasis should be placed on childcare specialities, highlighting differences in applied equipment and communication. Child-friendly equipment should be widely available, such as colourful tools and simple gifts, and during treatment greater attention should be paid to creating compliance. Adequate communication could help reduce the amount of analgesic given in children's emergency care.
\end{abstract}

Keywords: Communication; Compliance; First aid; Music therapy; Paediatrics

\section{Introduction}

Childhood injury remains among the leading causes for childhood morbidity (Jullien, 2021; Kendrick, 2019). The effectiveness of the emergency child care and first-aid is influenced by several external and internal factors, which often do not receive sufficient attention during treatment (Cristal et al., 2018). Most of the scientific literature focuses on first aid knowledge and skills. However, several other factors have an impact on the child's compliance and thus the success of intervention (Jones et al., 2020). During childcare it is important to pay attention to body proportions to apply different-sized devices and drug doses, but it also requires special communication. Its purpose is to receive information due to the corresponding life-age communication, thereby forming a trust between the provider and the patient to prevent distress and anxiety and to reduce the rate of pain. In case of trauma to the child, inappropriate communication treatment of fears and pain may complicate the establishment of compliance in the future, preventing the flow of the first care. Furthermore, incomplete communication during first aid can have negative effects on the outcome and recovery (Pancekauskaite and Jankauskaitè, 2018).

First aid can be defined as the primary care of injuries and conditions resulting from a sudden and life-threatening event that involve serious damage, until the arrival of professionals to the scene (Hunka and Kisiván, 2020). According to Panesar (2012), the term 'compliance' refers to patient compliance, thus compliant, passive behaviour.

In our research, the concept of compliance was interpreted differently. The first step in quick and effective treatment is the creation of sufficient cooperation and patient involvement in decision-making, by which the sense of loss of control can be reduced (Grootens-Wiegers et al., 2017). This interpretation was applied in our study, where patients were continuously informed about their condition and future duties, and those accompanying them were involved in their treatment. Indeed, cooperation is necessary in order to achieve the goal, however the phrasing creates a hierarchy in which the patient

\footnotetext{
* Corresponding author: Luca Anna Ferkai, MSc, PhD student, University of Pécs, Doctoral School of Health Sciences, 7/2 Koller street, Pécs 7626, Hungary; e-mail: ferkai.luca@gmail.com http://doi.org/10.32725/kont.2022.001 
is positioned at the bottom, and during the research we aimed to avoid this. Meaningful and informative interactions between patients and healthcare providers are an imperative and pragmatic component of a positive patient experience, and the manner in which information is transferred is critical to ensuring that the desired outcomes are achieved (Blackburn et al., 2019; Patel and Landrigan, 2019). Therefore, we tried to put more emphasis on the diversity of communication and its aspects to become tailored to the individual.

Music therapy may be helpful in modulating emotions by improving mood through emotional expression and may act as a non-pharmacological therapy to relieve procedural pain in patients. (Aalbers et al., 2017; Yaman Aktaş and Karabulut, 2019). During our experiment, from this approach we apply the preservation of the experiences as positive memories and the effect on compliance with the help of music. With our first aid situations at Lake Balaton the aim was to achieve a reduction in pain with the help of music. In our own research we aimed to reach these beneficial effects of music in case of children during first aid. Nowadays, one of the main scenes of communication between children and supplier is the hospital environment, where there is an extended period of contact with the patient, thus the need to improve the mood and to foster cooperation arise. To achieve this, puppet shows, story reading, acting or art therapy were applied, and a measurable improvement in children's state could be discovered (Béres et al., 2011). According to Siegel et al. (2016), serious injuries can cause psychological trauma to children. However, they also found that the mutual preparation of toys modifies the trauma into an emotional experience.

Albert et al. (2013) believe that the look of workwear should be developed separately for children, according to their specific needs.

Moutte et al. (2015) dealt with the creation of a measurable pain level of children. They thought that determination of the degree of pain is important for pain reduction, because it can increase the level of sympathy and compliance of the patients.

According to the research of Jennings et al. (2015) PSS, Wong-Baker scale (Facial Expression Scale) and FLACC scale (Face/Legs/Activity/Crying/Consolability) used in Australia, which studied 15,016 children, the degree of pain was managed to be reduced to a clinically significant degree in 12,346 (82.2\%)

FLACC scale was developed for children from 2 months to 7 years, to evaluate the degree of pain based on the criteria listed. In the case of the PSS scale, patients indicate the current strength of a pain on a scale ranging from 0 to 10 , where
0 means painless state, and 10 means the patient feels the strongest imaginable pain. This scale is applicable to all adults and children over 9 years, who can express the strength of pain with numbers. If the measured value of PSS is reduced after the treatment, the adequacy is certified. In case of VAS the experienced pain intensity is identified with the help of an image or shape (e.g., a line from 0 to 10, or the Wong-Baker's scale with face expressions) (Young, 2017).

Based on the above mentioned, during our research the aim was to explore how music used in the on-site first aid, along with the child-friendly communication tool, may alter psychological status, sense of pain and cooperation of children.

\section{Materials and methods}

\section{Study design}

Our research is an experimental study including quantitative and qualitative items. The quantitative element was the objective recording of the case sheet documentation's data, while the qualitative element was the observation and the special communication with the children and their parents/relatives/ other accompanying persons. The objective of the study was to prove that the average pain level, mood and behaviour of the case and the control groups will be different during children's first aid.

\section{Research sample}

The target group of this experimental research was selected by convenience sampling, it consisted of $80(n=80)$ children up to 16 years, who received first aid within the framework of the Balaton First Aid Service at Balatonlelle Napfény Beach and Water Park during the study period: 22/7/2016 to 11/8/2016. Their average age was 6.5 years (median: 6; SD: 3.26 ). Those who rejected the treatment were excluded from the study.

$G^{*}$ Power 3.1.9.7 software was used to determine the required sample size and statistical power. According to the results, the minimum value of the total sample size was 72 , the case groups should contain at least 53 people while the control group at least 19 people (Tails: two; a err. prob. 0.05; Power (1- $\beta$ err. prob.): 0.8; Allocation ratio N2/N1: 0.37). The central and non-central distributions of the sample size can be seen in Chart 1.

During the research, two case groups $(\mathrm{n}=58)$ and one control group $(n=22)$ were created. In the first case group $(n=25)$, to improve the level of compliance, relaxing music was used. In the other case group $(n=22)$, colourful equipment/tools

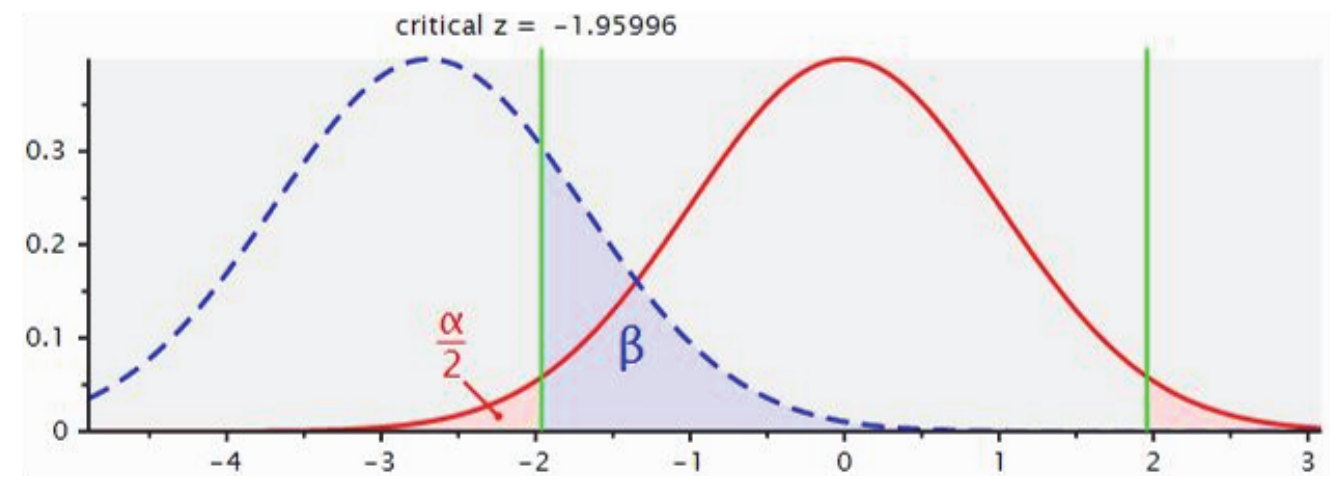

Chart 1. Central and non-central distributions of the sample size 
were used with cartoon and animal figures. In the control group, treatment was conducted using conventional methods $(n=22)$. Although special communication was used in both case groups, the research also aimed to assess the effect of music on compliance. Therefore, in the first case group the use of music during children first aid appeared independently.

\section{Data collection and analysis}

During data recording, the documentation case sheet, observation, Wong-Baker facial expression scale (FACES scale), and Pain Severity Score (PSS) was applied. During the study, after prior consultation at the site, a study design was established where one of the Red Cross volunteer first aid personnel became an observer, and the other had the supplier role. The observer recorded personal details and parameters of the children, monitored the smile/laugh frequency, the accompanying behaviour, and measured the time of supply and crying. The application of the Wong-Baker scale is proposed over three years, thus in case of younger children the degree of pain was determined by the person accompanying them. The collected data were analysed by descriptive statistics and $\chi^{2}$-test (the results were considered significant at $95 \%$ confidence interval, with $p<0.05$ value), and Cramer's association coefficient was applied.

\section{Used tools}

Data recording and statistical analyses were performed using IBM SPSS Statistics 22.0 and G*Power 3.1.9.7.

Tools used in the pilot study included different adult first aid equipment: animal patterned scissors, tick-tweezers, pupil lamp, waterproof bandage, colourful, floral uniform, smiling face gloves-balloons, plush toys, Panthenol cutaneous sprays, Novosil gel, Icemix freezer spray, Octenisept sanitiser spray, isolating foil, bubble, stickers, balloons, candy (also sugar-free version). The traditional adult and special children first aid kit used in the study can be seen in Fig. 1.

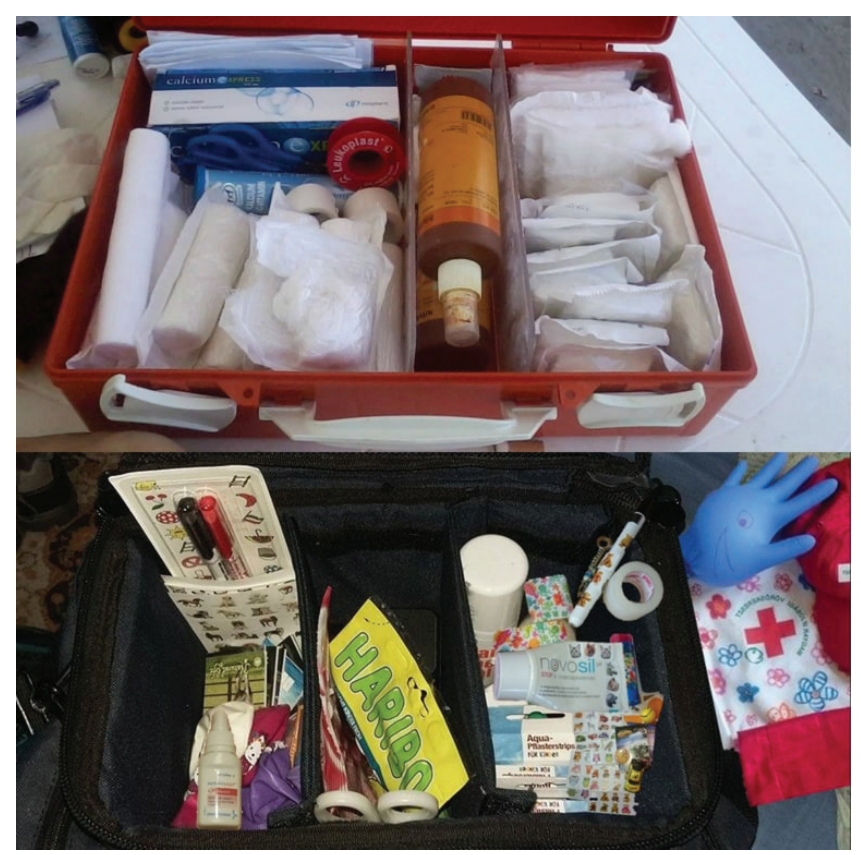

Fig. 1. Contents of traditional adult and special children first aid kit

\section{Results}

\section{Summarized results of the first aid intervention}

During the research period, 80 children received first aid. Pain intensity of children at the site had an average of 5.95 (median: 4) based on the Wong-Baker and PSS pain assessment scale (in the case of children who were younger than 16 years, but using the Wong-Baker's face scale was not appropriate, PSS experiencing pain scale was applied, thus the values can be converted into each other). After the treatment, this value dropped to 3.03 (median: 2). The average duration of first aid for one person was five minutes (SD: 2.91). Based on the location of the injury, lower limb injuries occurred most frequently (68.75\%). Further summarized results of the treated children are shown in Table 1.

Moderate relationship was shown between the type of pain and treatment outcome based on the results ( $p<0.001$; Cramer coefficient: 0.67$)$. The nature of pain affected the duration of treatment significantly $(p<0.001)$. Pain value measured before first aid service determined both the treatment period $(p=0.05)$, the degree of pain values after the treatment $(p<0.001)$, and treatment outcome $(p<0.001)$ as well. Significant correlation also appeared between the response and the age of the children $(p<0.001)$. Age did not show significant correlation with treatment duration $(p=0.74)$, the length of the crying period ( $p=0.15$ ), the change in pain values $(p=0.10)$, or the outcome of treatment $(p=0.73)$. The results show that the location of the injury influenced crying time $(p=0.05)$, the outcome of treatment $(p=0.01)$, and also the treatment time $(p=0.002)$. The results show that the gender of children receiving first aid did not significantly affect treatment period ( $p=0.36)$, crying time ( $p=0.77)$, pain value after treatment $(p=0.72)$, and the treatment outcome $(p=0.59)$.

\section{Results of the control group}

The control group consisted of 22 children, including 16 boys (72.7\%) and 6 girls (27.3\%). The initial pain level of these children was 5.18 on average (median: 4 ). The highest value of reported initial pain was 10, the lowest was 2. During pain assessment after treatment, the average pain score decreased to 3.55 (median 3), when the highest level of pain was 10, and the lowest is 0 . The duration of treatment was an average of 6.18 minutes (median: 5.5; SD: 3.05). The time of crying was 1 minute (median 0, SD 1.93) during the treatment. Number of smile/laughter was 1 in this group, an average of $0.05 \%$ (median: 0). None of the children smiled at the sight of the traditional, adult tools. The questions during the anamnesis were answered by 16 persons (72.7\%), 6 persons (27.3\%) did not respond.

\section{Results of the music intervention case group}

The music intervention case group included 25 people (31.25\%). 10 people of the injured children were boys (40\%) and 15 (60\%) were girls. The children reported average 6.24 pain intensity (median 4) prior to the first aid, the highest pain assessment was 10, and the lowest was 2 . After treatment, the average pain level reduced to 4.56 (median: 4 ). The highest value for pain was at 10 , and the lowest was 0 . The average duration of treatment was 5.12 minutes (median: 4; SD: 2.95), the average crying time was 1.92 minutes (modus: 0; SD: 3.07 ), the number of laughing/smile was 5 , an average of 0.16 . Seeing the traditional adult tools, none of the children smiled. When listening to music, 20 children (80\%) did not smile, 5 children 
Table 1. Summarized results of the first aid intervention

\begin{tabular}{|c|c|c|c|c|c|c|}
\hline \multirow{4}{*}{$\begin{array}{l}\text { Sex } \\
\text { Age }\end{array}$} & \multicolumn{3}{|c|}{ Male } & \multicolumn{3}{|c|}{ Female } \\
\hline & \multicolumn{3}{|c|}{$56.25 \%(45$ persons $)$} & \multicolumn{3}{|c|}{ 43.75\% (35 persons) } \\
\hline & Average & \multicolumn{2}{|c|}{ Median } & SD & Youngest child & Oldest child \\
\hline & 6.5 years & & 6 & 3.26 & 1 year old & 16 years old \\
\hline \multicolumn{7}{|c|}{ Injuries } \\
\hline Lower limb injuries & \multicolumn{6}{|c|}{$68.75 \%$} \\
\hline Upper limb injuries & \multicolumn{6}{|c|}{$17.5 \%$} \\
\hline \multirow{3}{*}{ Other categories } & \multicolumn{6}{|c|}{$13.75 \%$} \\
\hline & $\begin{array}{c}\text { Eye } \\
\text { injuries }\end{array}$ & $\begin{array}{l}\text { Nasal } \\
\text { njuries }\end{array}$ & Chin injuries & Chest injuries & $\begin{array}{c}\text { Spine } \\
\text { injuries }\end{array}$ & Sickness \\
\hline & $3.75 \%$ & $1.25 \%$ & $3.75 \%$ & $1.25 \%$ & $2.5 \%$ & $1.25 \%$ \\
\hline $\begin{array}{l}\text { Patient responsiveness } \\
\text { during anamnesis } \\
\text { recording }\end{array}$ & \multicolumn{3}{|c|}{$75 \%$ responded (60 persons) } & \multicolumn{3}{|c|}{$25 \%$ did not respond (20 persons) } \\
\hline \multirow{2}{*}{ The nature of pain } & \multicolumn{2}{|l|}{ Searing pain } & Pulsing pain & \multicolumn{2}{|c|}{ Stabbing pain } & Dull pain \\
\hline & \multicolumn{2}{|l|}{$70 \%$} & $15 \%$ & \multicolumn{2}{|c|}{$8.75 \%$} & $6.25 \%$ \\
\hline $\begin{array}{l}\text { Drug intolerance in the } \\
\text { past medical history }\end{array}$ & \multicolumn{6}{|c|}{ None of the accompanying persons knew about drug intolerance } \\
\hline \multirow{2}{*}{ Accompanying person } & \multicolumn{2}{|l|}{ Parents } & Oth & latives & No & atives \\
\hline & $91.25 \%$ & & & & & \\
\hline Behaviour of the & Calm & & & king & & ssive \\
\hline accompanying person & $93.75 \%$ & & & & & \\
\hline Direction of care & Onl & ly on-sit & are & Direc & to specialists/o & services \\
\hline Direction of care & & $86.25 \%$ & & & $13.75 \%$ & \\
\hline
\end{tabular}

were smiling (20\%). 17 children (68\%) responded to the questions, 8 (32\%) did not.

\section{Results of the complex intervention case group}

The complex intervention case group consisted of 33 (41.25\%) children. 19 of them were boys (57.6\%) and 14 girls (42.4\%). Initially, 6.24 pain value was reported (median 8), the highest pain assessment was 10, and the lowest was 0 . After the complex treatment, the average pain score decreased to 1.52 (median 0), the highest pain assessment was 10, and the lowest was 0 . The average duration of treatment was 4.73 minutes (modus: 3, SD 2.71). The average crying time was 0.58 minutes (modus 0; SD: 1.28). The number of smiles/laughter was 40, average 1.21 (median: 1 ). The sight of children friendly tools generated smiles in 22 children (66.7\%), and smiling was not observed in 11 of them (33.3\%). Listening to music triggered smiles in 7 (21.2\%) children, and $26(78.8 \%)$ did not smile. 27 children $(81.8 \%)$ responded to questions asked during the treatment, six did (18.2\%) not respond.

\section{Comparative results of the groups}

The initial average pain level of children at the time they arrived on the site were equal in the music intervention and complex intervention groups (mean $=6.24$; median: 4 ), while the lowest value was measured in the control group (mean = 5.18; median: 4). The greatest reduction in average pain scores was shown in the complex intervention group (mean $=1.52$; median: 0 ), followed by the control group (mean $=3.55$; median: 3 ), and finally the music intervention group (mean $=4.56$; median 4). A comparison of the average pain levels can be seen in Chart 2 .

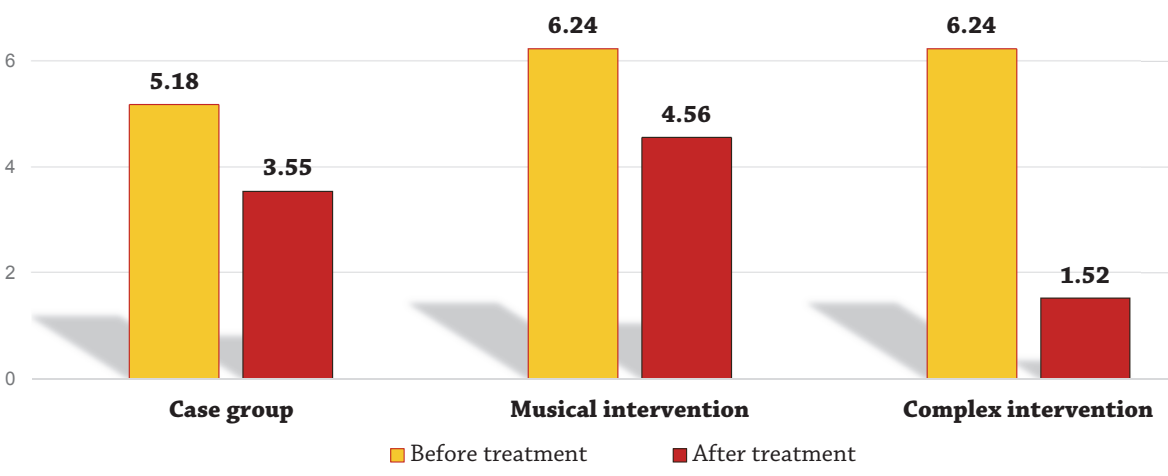

Chart 2. Changes in average pain value (Wong-Baker, PSS-scale) 
Significant correlation was shown between the type of communication and pain value measured after treatment ( $p=0.001$ ). This means that the applied colourful tools and rewards during children's first aid resulted in a significant decrease in the pain of children. The average duration of treatment was shortest in the complex intervention group (mean = 4.73 min; median: 4), followed by the music intervention group (mean $=5.12$ min; median 4 ), and the control group (mean $=6.18$ minutes; median 55). On average, the members of the complex intervention group were crying for the least time (mean $=0.58 \mathrm{~min}$; median 0 ). The time of crying was the longest in the musical intervention group (mean = $1.920 \mathrm{~min}$; median 0), and the value of the control group was located between the values of the two other groups (mean = $1 \mathrm{~min}$; median 0). A significant relationship between the communication intervention type and duration of crying was found, where $p=0.001$ (Cramer coefficient: 0.59). Duration of treatment and crying can be seen in Chart 3 .

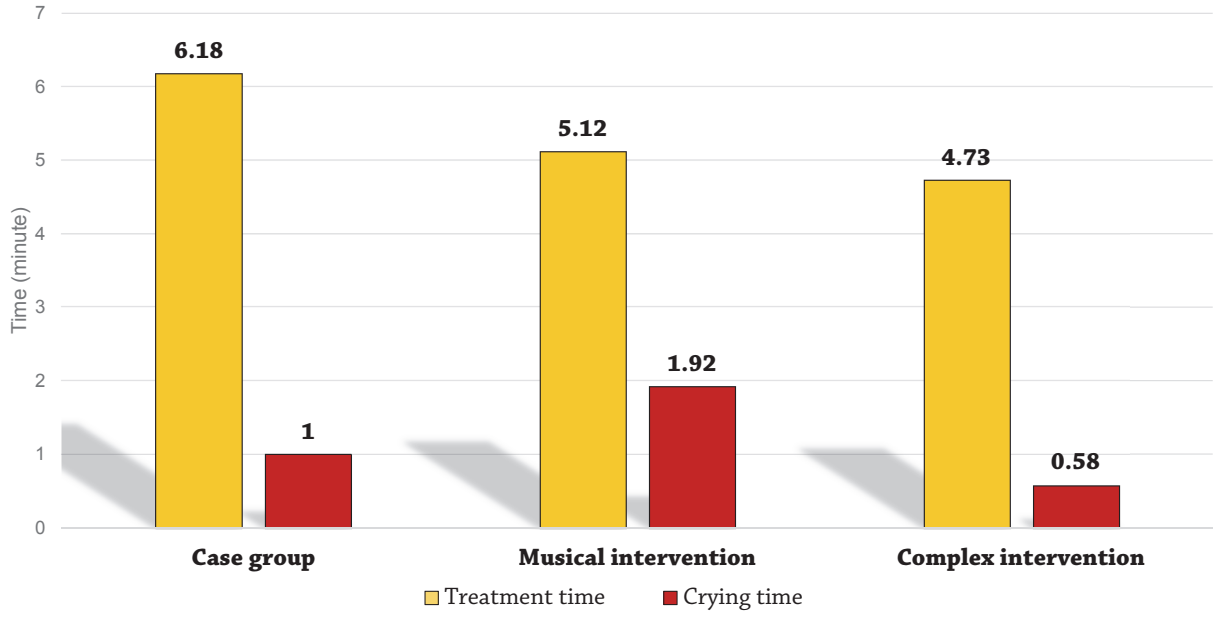

Chart 3. Duration of treatment and crying

Number of smiles/laughter was the highest in the complex intervention group $40(n=20$, mean $=1.21$; median: 1$)$, followed by the music intervention group: 4 (4 persons mean = 0.16 ; median 0 ), and finally by the control group 1 ( 1 person, mean $=0.05 \%$; median: 0 ). A significant correlation and moderate relationship may be justified between the nature of communication intervention and smiles that appear during treatment ( $p<0.001$; Cramer coefficient: 0.57). While none of the children from the control group and the music intervention group smiled at the sight of traditional instruments, among the 33 children belonging to the complex intervention group, $22(66.7 \%)$ smiled at the sight of child-friendly equipment, and only 11 (33.3\%) did not. The results showed that a significant correlation can be found between the nature of communication intervention and the smile response at the sight of child-friendly tools $(p<0.001)$. A strong connection can be seen between the nature of communication intervention and the number of smiles appearing as a response to child-friendly tools ( $p<0.001$; Cramer coefficient: 0.73). The occurrence of smiling and laughing can be seen in Chart 4 .

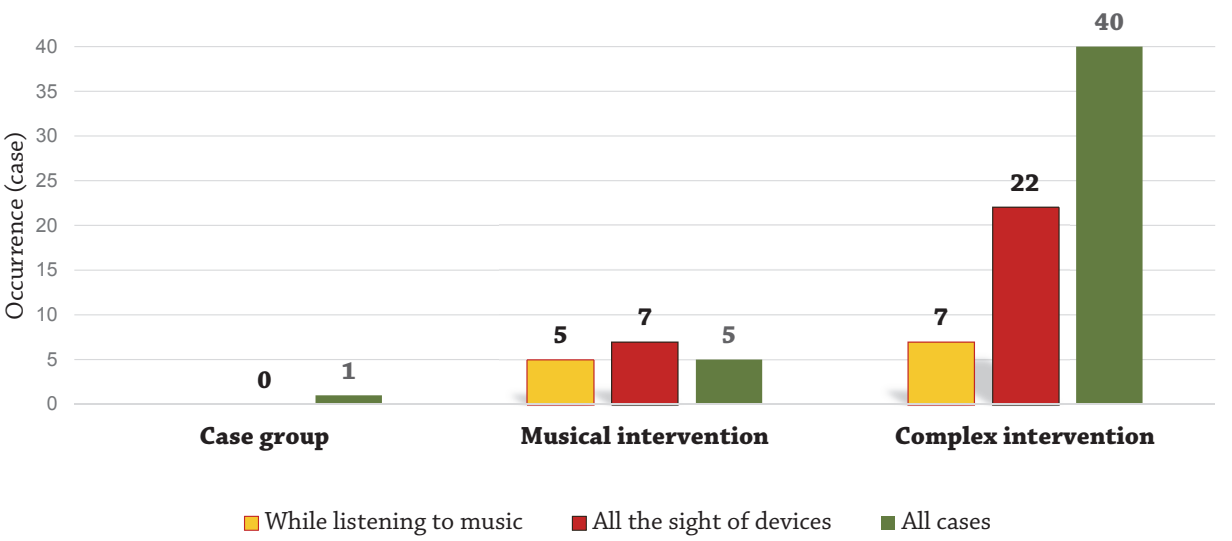

Chart 4. Occurrence of smiling and laughing (cases)

Colourful tools and rewards applied during first aid treatment of children result in a significant improvement in their mood and behaviour. Application of communication intervention on a larger case number may also affect the duration of treatment, since $p=0.07$. When listening to music, a few children smiled both in the complex and musical intervention groups (music intervention group: 5 persons, 20\%, complex intervention group: 7 persons, $21.2 \%$, only $20.67 \%$ of those receiving intervention). The questions during anamnesis were answered mostly by the complex intervention group (81.8\%), followed by the musical intervention group (68\%), and least likely to respond were the control group (72.7\%). Based on these results, a significant correlation was found between the duration of the treatment and the accompanying person 
( $p=0.001$ ). In $85.7 \%$ of the cases, daughters were accompanied by their parents at the site. In $8.6 \%$ of cases a relative accompanied them, and $5.7 \%$ of cases an acquaintance. The behaviour of those who accompanied the girls were calm in 32 cases (91.4\%), 2 were panicking (5.7\%), and 1 person (2.9\%) was aggressive. In $95.6 \%$ of the cases, sons were accompanied by their parents to the site, and $4.4 \%$ were taken by a relative. The results showed that the behaviour of the accompanying person significantly influenced the treatment outcome $(p=0.002)$ and treatment period $(p=0.007)$. However, it did not affect the reaction of children $(p=0.11)$, pain values recorded after treatment $(p=0.95)$, crying time $(p=0.34)$, smile appearance during treatment $(p=0.70)$, and whether the sight of tools $(p=0.41)$ or the sound of music $(p=0.40)$ initiated smiling.

\section{Discussion}

The experimental research demonstrated that the average pain level, mood and behaviour of the case and the control groups was different during children's first aid. The pain sensation was reduced by colourful tools and gifts to a greater extent than conventional tools of adult care. The fact that the children in the control group did not smile at the sight of the assets may be referred to as the absence of intervention. The frequent smile response of children may be associated with child-friendly equipment used in the treatment. In our study, we found that it was not only children who positively assessed the use of "child-friendly" tools, but also the person accompanying them, regardless of age and gender. The communication intervention reduced the duration of crying, while promoting the development of confidence during care. Compliance developed because of complex interventions, and as a consequence, treatment became faster. A valuable reward is motivating for the child, so parents can prepare rewards that are especially valuable for their children in advance, in cooperation with the health workers. However, it is important that a reward is carried out immediately after the treatment, and thus children connect the positive experience to the intervention. A well-selected and consistent reward that is given every time may establish compliance for the future (Baverstock and Finlay, 2019). In the experiment by Siegel et al. (2016), children created puppets, and nurses then measured the mood of children with the help of the Wong-Baker scale. Their results showed that the use of tools was proved useful as a raw material; it reduced fear and anxiety against tools in children in the long-term.

During the study of Drake et al. (2012), hospital nurses attended a training in which communication techniques could be acquired and nurses learned to use special children's activity kits. Based on their results, the kit improved communication skills, had a distracting effect and reduced children's anxiety. The authors recommend the use of similar sets.

Musical intervention did not lead to success. It is assumed the reason for this is that the interventions happened outside, where the external sound source volume suppressed the music, and the higher volume inhibited the exchange of information between the health worker and the child or parent. According to Stegemann et al. (2019), the therapeutic application of music can be successful if individualized and applicable for the patient. For this reason, it would be worthwhile to expand the library of music played during the treatments.

The accompanying people were calm most of the time, and therefore could be involved in the treatment, which reduced the anxiety of the children. When the behaviour of the attendant was calm, cooperation became easier and the duration of the information exchange was shortened, thus the time of treatment decreased. Meanwhile, this was not fulfilled in the case of a panicking or aggressive parent, where the behaviour of the parents hindered the efficiency and success of the service, as well as increased child anxiety.

Based on the results of Byczkowski et al. (2016), spiritual support, information, respect, attentive care, appropriate information, communication, analgesia, safe and child-centered environment, and continuity of care, are considered to be important by parents during the treatment of their children. If we pay more attention to those expectations throughout the care process, cooperation with the parents also becomes easier. In order to improve the compliance with communication in childcare, parents believe we should apply special "child-friendly devices", verbal and non-verbal signals appropriate to age, and reward children after care to develop positive memories.

The attendants had no information about drug intolerances of the children, and therefore the use of Octenidine disinfectant with hydrochloride content became important to replace the traditional povidion-iodine solution, since it does not cause anaphylactic reactions. The haemostatic characteristic must be highlighted, which can decrease a child's fear of the treatment. Octenidine is colourless and does not sting, which can be important, because during the research, many children were frightened by vivid colour solution or the indicated pain. In addition, consideration should be given to the use of blanket isolation/blister, as there is an increased risk for the development of hypothermia in case of the injury of small children. However, during child first aid, the use of calcium is not suggested, as it is scientifically proven that there is no effect of preventing anaphylaxis or reducing the degree of the already emerged anaphylaxis (Cardona et al., 2020). In the case of children, the need for drug administration provokes a stress reaction, rather than relief, thus we suggest that, due to the scarce resources, the use of special "child-friendly tools" applied in our research is easy to learn and the training is not time-consuming. However, this knowledge may greatly influence the success of childcare. Knowing this, we aim to repeat our research involving larger case numbers. Standardized communication training for the volunteers would be beneficial prior to further studies. The study was limited by the heterogeneous age groups of children, the lack of financial support and available time, and the low number of first aid providers that could be involved.

\section{Conclusions}

According to the study, more emphasis should be placed on childcare specialities in first aid and professional medical training, highlighting the differences in applied equipment and communication. Building trust by applying the techniques mentioned above will result in a significant improvement in the children's experience of pain, their mood and behaviour, and consequently, compliance. Special communication training should be provided regarding situations arising during childcare. Childcare providers should pay more attention to non-verbal communication and appearance (especially to facial expressions, smiles and clothing). Furthermore, child-friendly equipment should be widely available, such as colourful tools and simple gifts. Based on the results of the research, it can be stated that the application of special child-friendly equipment, rewards and proper communication techniques in clinical practice improves compliance and reduces the children's sense of pain. 
In future, this research could be expanded to include the examination of communication and equipment used in children's emergency and hospital care. In the professional environment, the application of techniques in childcare targeting higher compliance could result in reduced analgesic usage and more efficient care.

\section{Ethical aspects and conflict of interests}

The authors have no conflict of interests to declare.

\section{Authors' contributions}

LAF and KD designed the study. LAF and KD contributed equally to this work. LAF analysed and interpreted the data and wrote the manuscript. $\mathrm{KD}, \mathrm{BS}, \mathrm{BB}, \mathrm{AP}$ and JB provided scientific support and valuable advice. All authors proofread the manuscript and revised it critically. All authors read and approved the final manuscript.

\title{
Možnosti zvýšení součinnosti při poskytování první pomoci dětem
}

\begin{abstract}
Souhrn
Úvod: Efektivita první pomoci a akutní péče o děti je ovlivněna řadou vnějších i vnitřních faktorů, kterým často není při samotném ošetření věnována dostatečná pozornost. Cílem našeho výzkumu bylo posoudit faktory, které ovlivňují součinnost dětí v reálných situacích.

Metody: Naši cílovou skupinu tvořilo 80 dětí (<16 let), které potřebovaly první pomoc u jezera Balaton během letních prázdnin v roce 2016. Na rozdíl od běžné péče byl sledován vliv hudby, vybavení vhodného pro děti a odměn na součinnost dětí při poskytování první pomoci. Pro sběr dat byly použity pozorování, dokumentace zákroku, Wong-Bakerova škála a škála PSS (Pain Severity Score). Pro statistickou analýzu byla použita popisná statistika, $\chi^{2}$-test a Cramerův koeficient.

Výsledky: Výzkum zjistil, že hudba nevedla k žádným pozitivním změnám v chování a nesnížila strach ani bolest a že dokumentace zákroku se stala obtížnější. Barevné pomůcky a odměny však vedly k významnému zlepšení nálady dětí $(p<0,001)$, snížení bolesti $(p=0,001)$ a lepšímu chování $(p=0,07)$.

Závěr: $\mathrm{V}$ rámci školení první pomoci a odborné lékařské přípravy by měl být kladen větší důraz na specifika péče o děti s dưrazem na rozdíly v používaném vybavení a komunikaci. Mělo by být široce dostupné vybavení vhodné pro děti, například barevné pomůcky a jednoduché dárky, a během ošetření by měla být věnována větší pozornost zajištění součinnosti dítěte. Vhodná komunikace by mohla pomoci snížit množství analgetik podávaných v rámci dětské akutní péče.
\end{abstract}

Klíčová slova: komunikace; muzikoterapie; pediatrie; první pomoc; součinnost

\section{References}

1. Aalbers S, Fusar-Poli L, Freeman RE, Spreen M, Cf Ket J, Vink AC, et al. (2017). Music therapy for depression. Cochrane Database Syst Rev 11(11): CD004517. DOI: 10.1002/14651858. CD004517.pub3.

2. Albert NM, Burke J, Bena JF, Albert NM, Morrison SM, Forney J, Krajewski S (2013). Nurses' uniform color and feelings/emotions in school-aged children receiving health care. J Pediatr Nurs 28(2): 141-149. DOI: $10.1016 / \mathrm{j}$. pedn.2012.03.032.

3. Baverstock A, Finlay F (2019). Positivity and reward. Arch Dis Child Educ Pract Ed 104(4): 182. DOI: 10.1136/ archdischild-2019-317210.

4. Béres A, Lelovics Z, Antal P, Hajós G, Gézsi A, Czéh Á, et al. (2011). Can the smile cure? Diseased children's immune response can improve by visit of The Smiling Hospital Foundation's artists. Orv Hetil 152(43): 1739-1744. DOI: 10.1556/OH.2011.29228.

5. Blackburn J, Ousey K, Goodwin E (2019). Information and communication in the emergency department. Int Emerg Nurs 42: 30-35. DOI: 10.1016/j.ienj.2018.07.002.

6. Byczkowski TL, Gillespie GL, Kennebeck SS, Fitzgerald MR, Downing KA, Alessandrini EA (2016). Family-centered pediatric emergency care: A framework for measuring what parents want and value. Acad Pediatr 16(4): 327-335. DOI: 10.1016/j. acap.2015.08.011.

7. Cardona V, Ansotegui IJ, Ebisawa M, El-Gamal Y, Fernandez Rivas M, Fineman S, et al. (2020). World Allergy Organization Anaphylaxis Guidance 2020. World Allergy Organ J 13(10): 100472. DOI: 10.1016/j.waojou.2020.100472.

8. Cristal NS, Staab J, Chatham R, Ryan S, McNair B, Grubenhoff JA (2018). Child Life Reduces Distress and
Pain and Improves Family Satisfaction in the Pediatric Emergency Department. Clin Pediatr 57(13): 1567-1575. DOI: 10.1177/0009922818798386.

9. Drake J, Johnson N, Stoneck AV, Martinez DM, Massey M (2012). Evaluation of a coping kit for children with challenging behaviors in a pediatric hospital. Pediatr Nurs 38(4): 215-221.

10. Grootens-Wiegers P, Hein IM, van den Broek JM, de Vries MC (2017). Medical decision-making in children and adolescents: developmental and neuroscientific aspects. BMC Pediatr 17(1): 120-130. DOI: 10.1186/s12887-017-0869-x.

11. Hunka B, Kisiván Cs (2020). Handbook of first aid. Budapest: Medicina, 13 p.

12. Jennings PA, Lord B, Smith K (2015). Clinically meaningful reduction in pain severity in children treated by paramedics. Am J Emerg Med 33(11): 1587-1590. DOI: 10.1016/j. ajem.2015.06.026.

13. Jones S, Tyson S, Davis N, Yorke J (2020). Qualitative study of the needs of injured children and their families after a child's traumatic injury. BMJ Open 10(11): e036682. DOI: 10.1136/ bmjopen-2019-036682.

14. Jullien S (2021). Prevention of unintentional injuries in children under five years. BMC Pediatr 21(1): 311-322. DOI: 10.1186/s12887-021-02517-2.

15. Kendrick D (2019). Unintentional injuries and their prevention. In: Emond A (Ed.). Health for all children. Oxford: Oxford University Press, pp. 160-180.

16. Moutte SD, Brudvik C, Morken T (2015). Physicians' use of pain scale and treatment procedures among children and youth in emergency primary care - a cross sectional study. BMC Emerg Med 15: 33. DOI: 10.1186/s12873-015-0059-9.

17. Pancekauskaitė G, Jankauskaitè L (2018). Paediatric Pain Medicine: Pain Differences, Recognition and Coping Acute Procedural Pain in Paediatric Emergency Room. Medicina (Kaunas) 54(6): 94-114. DOI: 10.3390/medicina54060094. 
18. Panesar K (2012). Patient Compliance and Health Behavior Models. US Pharm 37(4): 12-14.

19. Patel SJ, Landrigan CP (2019). Communication at Transitions of Care. Pediatr Clin North Am 66(4): 751-773. DOI: 10.1016/j. pcl.2019.03.004.

20. Siegel J, Iida H, Rachlin K, Yount G (2016). Expressive arts therapy with hospitalized children: A pilot study of cocreating healing sock creatures. J Pediatr Nurs 31(1): 92-98. DOI: 10.1016/j.pedn.2015.08.006.

21. Stegemann T, Geretsegger M, Quoc EP, Riedl H, Smetana M (2019). Music Therapy and Other Music-Based Interventions in
Pediatric Health Care: An Overview. Medicines (Basel) 6(1): 25. DOI: 10.3390/medicines6010025.

22. Yaman Aktaş Y, Karabulut N (2019). Relief of Procedural Pain in Critically Ill Patients by Music Therapy: A Randomized Controlled Trial. Complement Med Res 26(3): 156-165. DOI: 10.1159/000495301.

23. Young VB (2017). Effective Management of Pain and Anxiety for the Pediatric Patient in the Emergency Department. Crit Care Nurs Clin North Am 29(2): 205-216. DOI: 10.1016/j. cnc.2017.01.007. 